\title{
ACESSIBILIDADE AO JURÍDICO-POLÍTICO PELOS SURDOS: DESAFIOS DO ATIVISMO NA POLÍTICA BRASILEIRA
}

\author{
Bruna S. Ribeiro, Heloisa Andreia de M. Lins.
}

\section{Resumo}

A acessibilidade para os surdos no cenário jurídico-político é o objeto da pesquisa em questão que propôs observar e mapear acontecimentos políticos como o julgamento de habeas corpus do ex-presidente Luís Inácio Lula da Silva e o discurso da primeira dama, Michele Bolsonaro, em Libras, na tentativa de compreender algumas tendências sobre a participação política dos sujeitos surdos nesse território. Para tanto, foram observadas algumas postagens - com matérias e vídeos - encontradas em mídias sociais, protagonizadas pela comunidade surda nos períodos acima mencionados e realizado um levantamento de pesquisas acerca do tema. Os principais resultados dessa cartografia foram: escassez de pesquisas acadêmicas que envolvam o ativismo surdo na política ( 08 pesquisas encontradas), deficiência nos órgãos responsáveis na divulgação de informações para a comunidade surda e falta de acessibilidade nos meios televisivos (como janela em Libras e closed caption nos programas que se propõem a debater questões políticas e notificar fatos nesse âmbito). Foram encontrados programas com tradução para Libras: a) na TV Cultura, o Jornal da cultura; b) na TV Brasil, o programa Repórter Visual, c) na TV INES, o jornal Primeira mão. Em função dessa lacuna no acesso institucional à informação e comunicação para a comunidade surda, foram encontrados vários canais no YouTube como: Visurdo, TV CES e Leo Viturinno.

Palavras-chave: acessibilidade, política, surdos.

\section{Introdução}

Os espaços atualmente ocupados pela população surda merecem pesquisas, também a respeito de como os surdos participam - do ponto de vista político - nesses locais. Isso significa também atentar para a acessibilidade que está sendo oportunizada no contexto jurídico-político, cuja linguagem é mais específica aos profissionais do Direito, o que certamente pode limitar a participação da comunidade surda. A surdez é campo de estudo comum a certas áreas do conhecimento, como pedagogia, psicologia e fonoaudiologia, contudo, quando observamos a produção científica em outras áreas, há certa escassez de pesquisas. Deste modo, questões em torno da participação política e sobre o ativismo do povo surdo são lacunares. Em função também desse aspecto, conhecimentos nesse âmbito são bastante necessários, para que possamos traçar linhas capazes de criar formas que explicitam onde os órgãos públicos e os responsáveis pela implementação de políticas públicas estão viabilizando (ou não) a acessibilidade para os surdos, após aproximadamente 17 anos da lei no 10.436/2002 que no segundo artigo assegura de modo institucionalizado o uso e difusão da Língua Brasileira de Sinais (LIBRAS)

\section{Resultados e Discussão}

O método cartográfico foi utilizado para referenciar a produção e análise dos dados desta pesquisa. Num primeiro movimento, buscou-se pelas pesquisas realizadas no contexto acima referido e publicadas em plataformas como "Scielo", "Portal de periódicos Capes" e "Biblioteca digital brasileira de teses e dissertações". Contudo, nota-se a escassez de produção acadêmica no tocante ao ativismo surdo e política, a partir da busca por essas palavras-chave nos referidos repositórios. A partir disso, houve a seleção de dados nas mídias sociais com 0 intuito de encontrar materiais que dialogassem com o objetivo em questão, como no caso do julgamento de habeas corpus do ex-presidente Lula e do discurso em Libras da primeira dama. Nesse percurso investigativo, observou-se que, embora sites como TV INES (portal do governo federal que possui o programa Primeira mão, jornal em Libras) não contêm matéria sobre as últimas eleições presidenciais. Além disso, outro meio como a TV Brasil, da EBC (Empresa Brasileira de Comunicação) em seu programa Repórter visual - disponível na internet também não contém informações sobre as últimas eleições ou algo relacionado ao tema que fora destaque nos meios ouvintes. Ademais, de acordo com a Pesquisa de Mídias, realizada pela Secretaria de Comunicação Social (SECOM), no ano de 2016, o primeiro lugar (de vinte e sete menções das emissoras mais assistidas pela população em geral) era a TV Globo, que em programas como o Jornal Nacional não contém janela tradutória para Libras, somente a áudio-descrição, Closed Caption (sistema de legendas nos meios televisivos). Em contrapartida, em décimo lugar nesse ranking, encontrase a TV Cultura que, em programas como Jornal da Cultura e Roda Viva, possui tradução e interpretação para Libras e Closed Caption nos demais programas, como Persona em Foco e Metrópolis.

\section{Conclusões}

Observa-se, desta forma, que além da dificuldade quanto ao oferecimento de conteúdos acessíveis - o que resvala em questões já garantidas pela legislação - como alternativa, a comunidade vem se utilizando dos meios informais (visuais), como canais no YouTube, páginas no Facebook e Instagram, com intuito de terem o mínimo de informação a respeito do que se passa no país, além da imprensa escrita, do ponto de vista político. A questão que daí decorre, portanto, é em relação ao tipo de informação que é produzida e circulada nesses âmbitos.

\section{Agradecimentos}

Agradeço à orientadora Heloísa Andreia de Matos Lins pelo compartilhamento de conhecimento, diálogo e paciência para orientar as problemáticas provindas da pesquisa, além das dúvidas no percurso, enriquecendo minha carreira acadêmica, ademais agradeço ao SAE (Serviço de Apoio ao Estudante/UNICAMP) e o CNPq (Conselho Nacional de Desenvolvimento Científico e Tecnológico) como órgãos de apoio financeiro.

HONNETH, A., Luta por reconhecimento - a gramática moral dos conflitos sociais. Editora 34, São Paulo,2003. 